\title{
Notes on the Role of the Basel Manuscripts in Sixteenth-Century Protestant Literature of the Grand Duchy of Lithuania*
}

In 1563 in Nieśwież there appeared a hymnal printed by a typographer of the Kwieczyńscy publishing house - Daniel of Łęczyca. ${ }^{1}$ The hymnal contained two catechisms: Pierwszy katechism, to iest summa wiary krześcijaniskiey dla dziatek mnieyszych and Wtory Katechism szerszy dla więtszych y ćwiczenszych dziatek. The first of the texts is to be found in almost all Calvinist hymnals that appeared until the mid-seventeenth century. I have already discussed the possible sources of it and the role it played in the history of the Calvinist literature of the Crown and the Great Duchy of Lithuania. ${ }^{2}$ The story of the other text is quite different (henceforward referred to as Większy katechzim): it wasn't included in any of the Polish and Lithuanian hymnals (except for the one that appeared in Nieśwież). In this essay I am going to touch on the issue of the sources of the text, attempting to add to our knowledge of the role of Basel manuscripts in Protestant literature of the period.

* This article was written with the help of a research scholarship awarded by the International Centre of Culture in Kraków (Międzynarodowe Centrum Kultury w Krakowie) Sept.-Oct. 2010.

${ }^{1}$ Katechizm albo krótkie w iedno mieysce zebranie wiary i powinności chrześcijańskiej. The only copy that appear in bibliographies survives (without a title page) in the Library of the University of Uppsala (photocopy: Warsaw, National Library [Biblioteka Narodowa, hereafter: BN], sign. Fot.4.165).

${ }^{2}$ Cf. M. Korzo, "W sprawie jednego z XVI-wiecznych katechizmów kalwińskich w Rzeczpospolitej,” Odrodzenie i Reformacja w Polsce 51 (2007), pp. 177-198. 
The editors of the Nieśwież edition don't reveal their sources. In Przedmowa do pobożnego krzescianina they only point out that the hymnal was composed of different catechisms (fol. A2), while in a preface to the Psalms (fol. K8) they mention Katechizm Krakowski which came into existence around 1558 and which was later lost. Both remarks referred only to the song material, which was partially modified in comparison with previous hymnals. It is through the analysis of the song content that Alodia Kawecka-Gryczowa has been able to establish that the Nieswież print "originated from the circle of the already arianized Lithuanian ministers" and that there are some clear Anabaptist traces to be detected in the songbook. ${ }^{3}$ However, it is also possible to discern some inconsistencies: The Son of God that appears on the Nicene Symbol ${ }^{4}$ included in Pasterstwo Domowe is "uncreated" ("niestworzony", fol. E7ver.) and Modlitwa, ktorej wierne owieczki Krystusowe... często używać maja contains the following phrase: "Stłum i te, ktorzy są ku zgorszeniu Cerkwi [- - ] syna twego namilszego i Ducha Sw. bluźnią" ("Suppres those because of whom the Orthodox Church suffers indignation [- $]$ and who insult your Dearest Son and Holy Spirit", fol. Ii8ver.). ${ }^{5}$ Editors of Calvinist hymnals published later in the Crown and Lithuania also accused the Nieśwież edition of Anabaptist leanings. ${ }^{6}$ There was no criticism of Większy Katechizm, but it must have aroused some suspicions because it was removed from the songbooks.

The author of Większy katechizm remains unknown. It is sometimes suggested that the work was a translation of Szymon Budny's catechism that had been published one year earlier in Old Ruthenian (Katibisis to est nauka starodavnaâ hristianskâa [Nieśwież, 1562]), ${ }^{7}$ although Budny's version is greater in volume and the way the material it contains

${ }^{3}$ A. Kawecka-Gryczowa, "Kancjonały protestanckie na Litwie w w. XVI," Reformacja $w$ Polsce 4 (1926), p. 130-132.

4 The editors of the Nieśwież hymnal must have hoped to reach members of the Orthodox Church. It is with this goal in mind that they included in Pasterstwo domowe the Nicene Symbol, "ktorego isz po dziś dzień używaią w Greckich Cerkwiach Ruskich dla tego iest tu włożone" ("which has been placed here because it is still in use in Greek and Ruthenian Churches", fol. E7ver.). The Symbol ("Symbolum albo społek") can also be found in hymnals which were later published in Wilno. This profession of faith is absent from Jakub Sylwiusz' original version of Pasterstwo (d. after 1583) and in Calvinist hymnals from the Małopolska region.

5 Quoted after: Kawecka-Gryczowa, "Kancjonały," p. 131.

${ }^{6}$ Cf. Korzo, "W sprawie jednego z XVI-wiecznych katechizmów,” pp. 188-189.

${ }^{7}$ Cf. J. Kamieniecki, Szymon Budny - zapomniana postać polskiej reformacji (Wrocław, 2002), p. 68. 
is arranged is quite different. Alodia Kawecka-Gryczowa and Georgij Âkovlevič Golenčenko consider Budny to be one of its authors because the Polish text, they claim, contains entire paragraphs taken from his catechism and pointing to the later advocate of the baptism of adults (I shall return later to these possible borrowings). ${ }^{8}$ The years 1562-1563 were actually crucial to the spiritual life of both Budny and many of his associates in Lithuania and it can't be ruled out that he was involved in composing and editing the 1563 Nieśwież edition.

However, a closer examination of the text of Wiekszy katechizm supports the conclusion that we are dealing here with a modified version of one of the Basel catechisms. Created in the initial phase of the development of the Reformation in this city, throughout the sixteenth century it served as the basis for religious education in schools and parishes. The text in question was written by a distinguished humanist and one of the fathers of the Basel Reformation, Johannes Oekolampad (actually Johannes Huschin 1482-1531). ${ }^{9}$ It isn't known when the original version of Frag und Antwort was created. The earliest printed version which can be found in bibliographies comes from about 1537. Ferdinand Cohr dates the composition of the catechism to the years 1525-1526; Oekolampad's text, says Cohr, contains passages aimed against the Anabaptists whose activity was at that time becoming a source of many problems for Basel. According to this scholar, the specific treatment of the Lord's Supper clearly indicates that the fragment came into being after 1525, that is, after the Swiss reformers became engaged in a dispute with their Wittenberg counterparts over the understanding of this sacrament. ${ }^{10}$ On the eve of the Baden Disputation (1526) Oekolampad gave his support to Zwingli. ${ }^{11}$

${ }^{8}$ Cf. Kawecka-Gryczowa, "Kancjonały,” p. 130; G.A. Golenčenko, "Simon Budny. Knigoizdatelskaâ deâtel'nost' v Belarussii," in: Iz istorii knigi, bibliotečnogo dela i bibliografii v Belorussii, Pt. 1 (Minsk, 1970), p. 173. See also S. Kot, "Budny, Szymon," in: Polski stownik biograficzny, vol. 3 (Kraków, 1937), p. 97.

${ }^{9}$ Cf. R.C. Walton, "Oekolampad, Johannes," in: The Oxford Encyclopedia of the Reformation, ed. H.J. Hillerbrand, vol. 3 (New York and Oxford, 1996), pp. 169-171.

${ }^{10}$ Cf. F. Cohrs, Die evangelischen Katechismusversuche vor Luthers Enchiridion, vol. 4: Undatierbare Katechismusversuche und Zusammenfassende Darstellung (Berlin, 1902; Monumenta Germaniae Paedagogica, vol. 23), p. 6.

${ }^{11}$ A.N. Burnett, Teaching the Reformation. Ministers and Their Message in Basel, 1529-1629 (Oxford, 2006), p. 31. Oekolampad's treatise about the Supper entitled Genuina expositio (1525) was created in connection with the Baden disputation (cf. Walton, “Oekolampad, Johannes," pp. 169-171). The oldest Basel form, published in 1526, of holding the Supper (the so-called Abendmahlsliturgie) 
Amy Nelson Burnett argues for dating the creation of the catechism to the years 1529-1530, since many of Frag und Antwort's passages bear resemblance to relevant passages from the Basel Agenda, which was brought into being just in $1529 .{ }^{12}$ At that time the Anabaptists still posed a threat for the Reformation movement in Basel. ${ }^{13}$ Scholars also refer to two editions from the 1530s: in both cases Oekolampad's text and the Agenda form one printing block ${ }^{14}$ and this continued at least until the 1570 s. ${ }^{15}$

About 1544 Oekolampad's catechism was profoundly revised by Oswald Myconius (actually Oswald Geisshüsler, 1488-1552). Working closely with Ulrich Zwingli in Zurich, in 1531 Myconius moved to Basel where he filled Oekolampad's university position (after the latter's death) and became head of the church (antistes). ${ }^{16}$ The first

is ascribed by tradition to Oekolampad, although there is no evidence for this; cf. J. Markus, Die Einheit des Abendmahlsgottesdienstes bei den elsässischen und schweizerischen Reformatoren (Zürich and Stuttgart, 1968). The next edition of Abendmablsliturgie appeared in 1529 (cf. Burnett, Teaching the Reformation, p. 48).

12 Cf. "Die Basler Reformationsordnung, 1529 April 1," in: Aktensammlung zur Geschichte der Basler Reformation in den Jahren 1519 bis Anfang 1534, ed. E. Dürr, p. Roth, vol. 3: 1528 bis Juni 1529 (Basel, 1937), pp. 383-410.

13 Cf. Burnett, Teaching the Reformation, p. 312, n.; E.M. Wilbur, A History of Unitarianism. Socinianism and its Antecedents (Cambridge, 1946), p. 57. Let's note in passing that the first municipal order against the adherents of rebaptism was issued in the summer of 1527 while the second in March 1528 (cf. Aktensammlung zur Geschichte der Basler Reformation, vol. 2: Juli 1525 bis Ende 1527 (Basel, 1933), pp. 634-636; vol. 3, pp. 56-57).

${ }^{14}$ Cf. Frag und Antwort in verhörung der Kinder der Kilchen zů Basel. Kurz gestelt durch doctor Johann Ecolampadium (Basel: Jacob Kündig, [ca. 1537]), pp. 2-8; Form der Sacramenten bruch, wie sy zu Baselgebrucht werden mit sampt eynem kurtzen kinder bericht (Basel: Schouber, 1537; reprint in: Cohrs, Die evangelischen Katechismusversuche, vol. 4, pp. 13-17. Based on this edition Cohrs claims the catechism's original title was Kinderbericht).

15 Cf. Frag und Antwort: Form der Sacramenten bruch (Basel, 1545); Agend biechlin der Kirchen zů Basel (Basel, 1550), pp. 97-108; Agend Büchlin der Kirchen zů Basel (Basel, 1564), pp. 61-67; Agendtbüch Oder Christliche Kirchenbrüch und übung wie die zu Basel under Gottes gemein gehalten werden daruon volgends blat bericht gibt (Basel, 1569), pp. 61-67 (cf. E. Staehelin, "Oekolampad-Bibliographie. Verzeichnis der im 16. Jahrhundert erschienenen Oekolampaddrucke," Basler Zeitschrift für Geschichte und Altertumskunde 17 (1918), pp. 1-119, nos. 194, 203, 207, 215, 217). Reprint of Frag und Antwort (without information about the edition) also in: K.R. Hagenbach, Johann Oekolampad und Oswald Myconius die Reformatoren Basels. Leben und ausgewählte Schriften (Elberfeld, 1859), pp. 296-301.

${ }^{16}$ Cf. R. Rosin, "Myconius, Oswald," in: The Oxford Encyclopedia of the Reformation, vol. 3, p. 118. 
to be created was the Latin version of the work and the language in which it was written was, as explained in the preface dated 9 October 1544, chosen exclusively for educational reasons. ${ }^{17}$ There were a few editions of Myconius' Latin version in the sixteenth century, all of them bearing the title Institutio Christiana, sive Catechismus puerorum Reipublicae Basiliensis. In 1545 Myconius prepared the German translation of the work. ${ }^{18}$ Its first edition (referenced in bibliogaphies) Christliche fragstuck, nit allein für die jungen kinder, sonder auch für alte unnd ungeleerte lütt vast nützlich und notwendig appeared about $1550 .{ }^{19}$ It is this German version that was included in the Basel Agenda of which, at least from 1569, both Oekolampad's Frag und Antwort and Myconius' version were a part. ${ }^{20}$ There are also editions in which Oekolampad's catechism and its version prepared by Myconius were coupled with the Basel Confession, which can be taken as an indication of the high regard in which the texts were held until the 1720 s. One of the editions was prepared by Johan Jakob Grynaeus (1540$1617)^{21}$ who served in Basel in 1585 as antistes. He introduced some changes to Myconius' version, giving it a Calvinist hue. In 1620 the catechism was also published by a historian and theologian Johann Jakob Grasser (1579-1627). ${ }^{22}$ The German version was also in use outside Basel: in 1580 the text was edited by Mülhausen theologians and published to meet the needs of the local community. ${ }^{23}$

${ }^{17}$ I haven't been able to find the 1544 edition. A preface (identical in all the later editions) is to be found in: Briefe und Akten zum Leben Oekolampads. Zum vierhundertjährigen Jubiläum der Basler Reformation, ed. E. Staehelin, vol. 2 (Leipzig, 1934), p. 804.

${ }^{18}$ Cf. E. Staehelin, Das theologische Lebenswerk Johannes Oekolampads (New York and London, 1971), p. 589.

${ }^{19}$ Cf. Briefe und Akten zum Leben Oekolampads, vol. 2, p. 805. Fragments of Myconius' German version (without information about the edition) in: Hagenbach, Johann Oekolampad.

${ }^{20}$ Cf. A.N. Burnett, "Basel's Long Reformation: Church Ordinances and the Shaping of Religious Culture in the Sixteenth Century," Zwingliana 35 (2008), p. 149; eadem, Teaching the Reformation, p. 51.

${ }^{21}$ Cf. Das geistliche und herzliche Kleinod der Kirchen Gottes in Stadt und Landschaft Basel (Basel, 1590).

22 Cf. Compendium Theologiae Sacrae, tripartitum, Vereque Methodicum. Accessit Expositio tum Catechismi, tum Confessionis Basiliensis (copy Wolfenbüttel, Herzog August Bibliothek, hereafter: HAB, sign. A: 680.52 Theol.[1]).

23 Cf. Catechismus, oder Kinderbericht für die Kirchen und Gmeind Gottes in der Statt Mülhausen (Zürich, 1580; reprint in: J.M. Reu, Quellen zur Geschichte des kirchlichen Unterrichts in der evangelischen Kirche Deutschlands zwischen 1530 
Oekolampad's Frag und Antwort is a small catechism that contains 43 concise questions and answers. ${ }^{24}$ After a brief introduction (questions 1-6: Are you a Christian? Will you stand firm in your faith even during persecutions? What distinguishes a true Christ follower?) it successively discusses: the apostolic profession of faith (7-8), the Decalogue (9-23), the indispensability of baptism for being a true Christian and the issue of re-baptism (24-28), a prayer and God's Word (29-35), the principles of good behaviour (36-38), a fast (39-40), the Lord's Supper (41-42). The last question is a brief recapitulation of the whole. Oekolampad began his account with the Creed, and in doing so he followed the model of medieval catechisms. ${ }^{25}$ The arrangement of catechetical text in which the Creed precedes the Decalogue was going to become characteristic mainly of Catholic catechisms. ${ }^{26}$ The Creed also came first in many catechisms of the first generation reformers (for example, Andreas Althamer (1500-1539), ${ }^{27}$ Konrad Sam (1483-1533), ${ }^{28}$ Johannes Brenz (1499-1570), ${ }^{29}$ in the Bohemian Brethren's teachings from the beginning of the sixteenth century $^{30}$ and in the German translation of the catechism of the Unity - Kinderfragen from 1521-1522). ${ }^{31}$ In their early catechetical works

und 1600, Pt. 1: Quellen zur Geschichte des Katechismus-Unterrichts, vol. 1: Süddeutschland Katechismen [Gütersloh, 1904], pp. 155-167).

${ }^{24}$ I use the reprint of the 1537 edition in: Cohrs, Die evangelischen Katechismusversuche, vol. 4, pp. 13-17. I deliberately omit here the problem of the possible sources of Oekolampad's text.

${ }^{25}$ Cf. for example, one of the printed catechisms valued by the first generation reformers Fundamentum aeternae felicitatis omnibus hominibus utilissimum (Coloniae, 1497; Lipsiae, 1499; copy Cracow, Jagiellonian Library [Biblioteka Jagiellońska], sign. Inc. 2607).

${ }^{26}$ Cf. Ch. Weismann, Die Katechismen des Johannes Brenz, vol. 1: Die Entstehung, Text und Wirkungsgeschichte (Berlin, 1990), pp. 85-86.

27 Cf. Catechismus. Das ist Unterricht zum Christlichen Glauben (Nürnberg, 1528).

${ }^{28}$ Cf. Christliche underweysung der Jungen in Fragßweis (Augsburg, 1528).

29 Cf. "Fragstück des christlichen Glaubens, ca. 1527-1528," in: Weismann, Die Katechismen, pp. 661-684. Latin version: Catechismus minor pro pueris, in: Philippus Melanchthon, Catechismus puerilis, id est, institutio puerorum sacris. Ad pueros (Vittenbergae, 1536), fol. E4-E6ver.

${ }^{30}$ Cf. "Otázky dětinské prvnie," in: A. Molnár, Bratr Lukáš Bohoslovec Jednoty (Praha, 1948), pp. 120-121.

${ }^{31}$ Cf. "Catechismus. Ein Christliche underweisung und Vorschrift den Jungen im Glauben,” in: Deutsche Katechismen der Böhmischen Brüder, introd. A. Molnár, Pt. 1: J. Müller, Die deutschen Katechismen der Böhmischen Brüder, Pt. 2: J.A. Comenius, Die Uralte Christliche Catholische Religion (Hildesheim and New York, 1982), pp. 9-28. 
John Calvin (1509-1564) ${ }^{32}$ and Martin Bucer (1491-1551) ${ }^{33}$ also began their exposition of the principles of faith with the Creed. After the publication of Martin Luther's Small Catechism, the evangelical catechetical writings of all hues became dominated by the model in which the introduction to the principles of faith opened with the account of the Ten Commandments.

According to scholars, Frag und Antwort combines the traits of both the medieval and the early Reformation catechesis. ${ }^{34}$ The text provides no explanation of the particular parts of the profession of faith and the Lord's Prayer. It pays too little attention to the issue of sacraments - dealing mainly with the Ten Commandments (fifteen questions out of forty three) - and it is more concerned with the Christian code of conduct than with the Christian faith. These are the traits that set Oekolampad's catechism apart from the later evangelical ones.

Although Myconius' version was almost three times larger than the original text (with all the additions the catechism consists of 115 questions and answers), its subtitle retained the phrase: D. Ioannis Oecolampadii catechismus. Myconius' editorial work consisted mainly in supplying the missing fragments. ${ }^{35} \mathrm{He}$ included in his version the full texts of the Creed, the Decalogue and the Lord's Prayer because Frag und Antwort contained only their initial paragraphs. Oekolampad's first question: "Bist du eyn Christ?", is followed by an extensive paragraph devoted to the sacrament of baptism which, introduced by his successor, changed the arrangement of the whole work. The succession of chapters the Creed - the Decalogue - baptism - prayer the Supper was replaced by the one baptism - the Creed - the Decalogue - prayer - the Supper. The changes can at first sight be taken to express the polemic with the Anabaptism, but Myconius (just like Oekolampad) didn't deal with the issue of re-baptism until after the account of the Ten Commandments and he literally translated

32 Cf. "Institution puerile de la doctrine chrestienne faictepar maniere de dyalogue," in: Ioannis Calvini opera quae supersunt omnia, ed. J.W. Baum, E. Cunitz, E. Reuss, vol. 22 (Brunsvigiae, 1880), colls. 97-114; "Catechismus Genevensis," in: ibidem, vol. 5 (Brunsvigiae, 1866), colls. 315-362.

33 Cf. Kurtze schriftliche erklärung für die Kinder und angohnden (Strasburg, 1534).

${ }^{34}$ Cf. Burnett, Teaching the Reformation, p. 53.

35 I use the following edition: Institutio Christiana, sive Catechismus puerorum Reipublicae Basiliensis (Basileae, [after 1544]; copy Dresden, Sächsische Landesbibliothek - Staats- und Universitätsbibliothek, sign. Theol.ev.cat.289). 
Oekolampad's text without adding any details. What we are dealing with here isn't a polemic but an attempt to copy a certain pattern.

There are few catechisms arranged in this way in the Reformation writings. Of the most known works one can cite here those by Johannes Brenz, Kaspar Gräter (1501-1557) ${ }^{36}$ and Johann Baumgart (1514-1578). ${ }^{37}$ In accounting for this arrangement of particular chapters (baptism - the Creed), the authors mentioned above referred to the fragment of St. Mark's Gospel: "he that believeth and is baptized shall be saved" (Mk 16:16). An analogous justification was also used in the medieval catechism referred to above and entitled Fundamentum aeternae felicitatis. ${ }^{38}$ In Frag und Antwort Oekolampad's discussion of baptism follows the exposition of the Ten Commandments and is treated as the second commitment which the followers of Christ are required to take upon themselves. If it is difficult to establish whether the Basel Institutio Christiana drew to any extent on Gräter's work (as a certain model to be followed), then Myconius' familiarity with Benz's catechism is quite probable. In the years 1516-1518 Benz served as Oekolampad's assistant and later he still maintained close relationships with him. ${ }^{39}$ Benz's catechetical works were certainly part of the Basel collection. When it comes to the way in which the sacrament of baptism is interpreted in Institutio Christiana Myconius stressed mainly the effect of baptism upon the faithful, that is, upon their rebirth and the purgation of original sin. He didn't speak of it in terms of the entry into the visible Church.

To the full text of the Creed, Myconius added the account of the particular articles of it. Of particular note are the newly added parts regarding Christ's descent into Hell and the attributes of the true Church. ${ }^{40}$ The descent is treated rather in a medieval manner, that is literally, as the salvation of those who had died before Christ ("Patres liberavit, ad infernum damnatos propter Peccatu(m) originale: et sic liberavit, ut agnosceremus effectus miserationis Christi,

36 Cf. Catechesis oder underricht der Kinder, after Aug. 1528; reprint in: F. Cohrs, Die evangelischen Katechismusversuche vor Luthers Enchiridion, vol. 2: 1527-1528 (Berlin, 1900; Monumenta Germaniae Paedagogica, vol. 21), p. 325.

37 Cf. Des Catechismi Christliche unnd Heilige Kinderleer, 1552.

38 Cf. Weismann, Die Katechismen, pp. 282-283.

39 Cf. J.M. Estes, Christian Magistrate and State Church: The Reforming Career of Johannes Brenz (Toronto, 1982), p. 3.

40 It concerns the Church made up of true followers of Christ, a group from which Catholics were excluded. 
quousque pertigisset: tum ut nos in Domino mortui, eo descendere non cogeremur $\langle\ldots\rangle$ ", fol. A5ver.). Calvin and most evangelical theologians advocated a non-literal, symbolic interpretation of this article, viewing the descent into Hell in terms of the reminder of Christ's cross suffering. Myconius' views of the issue resemble those held by Oekolampad. One is even led to think that the passage about the descent is based on the text of the Basel reformer. ${ }^{41}$ In Institutio Christiana the Creed is directly followed by the only anti-Jewish polemical motif to be found in the catechism: Contrary to what the Jews say about Messiah, Christ didn't remain on earth but ascended to heaven. ("Dominu(m) non mansisse in terris (quod Iudaicus error de Messia conceperat), sed ascendisse in coelum", fol. A5ver.).

Of all the articles of the apostolic profession of faith, the attributes of the true Church are given the closest attention. Myconius included among them God's Word and the sacraments established by Christ. The rituals were assigned a secondary role. He believed the fear of God to be the internal sign of being part of the Church (fol. A6-A6ver.) and in support of this claim he cited St. Augustin - the only non-biblical citation found in the whole catechism.

Myconius included the commandments in the chapter devoted to the Decalogue. However, he didn't quote verbatim particular fragments from the Book of Exodus, but provided his own summaries of them. His version is lacking in the prohibition of painting pictures and the division of biblical text $(3+7)$ is more in the Catholic and Lutheran tradition than in the mature tradition of Calvinism. Added to Frag und Antwort is also the exposition of the commandments and the particular requests of Lord's Prayer.

The fragment about Lord's Supper was also expanded to include six new questions: why was this sacrament given this name and what do the faithful eat for Supper that Lord's Body and Blood are partaken of in a spiritual way ("modo non naturali, sed per animam fidelem", fol. B5ver.) and that Supper might be not only the source of salvation but also of spiritual death. The fragment was brought into being at the time when Basel declared itself on the side of Concordia Wittenbergensis (1536), which created a temporary tension in the relations with Zwingli's successor - Johann Heinrich Bullinger (1504-1575).

${ }^{41}$ Cf. "Oekolampad an Erasmus Ritter und Benedikt Burgauer, Basel, den 11. November 1528," in: Briefe und Akten zum Leben Oekolampads, pp. 251-253; Burnett, Teaching the Reformation, fn. on p. 313. 
In his letter from 14 March 1545 he even demanded that Myconius send him the already published catechism because he held some doubts as to the propriety of some of the statements it contained. ${ }^{42}$ The exposition of the sacrament of the Last Supper in Institutio Christiana has much to do with the first Basel Confession from 1534. Elaborated by Myconius on the basis of Oekolampad's Oratio (from 26 Sept. 1531), it was addressed for the Basel Synod. Myconius put in it a brief paraphrase of the apostles' Creed. ${ }^{43}$ Working on the text of the catechism, he tried to reconcile different standpoints, while at the same time taking his distance from the Anabaptist view that wine and bread are only the "naked signs" of Christ's blood and bread. Although Oekolampad's catechism was held in high regard (this holds true for both of its versions), in the latter half of the sixteenth

${ }^{42}$ Cf. A.N. Burnett, "Basel and the Wittenberg Concord," Archiv für Reformationsgeschichte 96 (2005), p. 48.

${ }^{43}$ Cf. "Oratio habita in Synodo, anno 1531," in: Oecol[ampadius], Ennaratio in Evangelium Matthaei et alia nonnulla quae sequenspagella indicabit (Basileae, 1536; copy HAB, sign. Yf 11.8 Helmst.), fol. 191ver.-193. The confession consisted of twelve articles of various anti-Catholic hue and contained fragments directed against the Anabaptists. Absent from it was an article about the Holy Scripture; cf. Reformed Confessions of the 16th Century, ed. and historical introduction A.C. Cochrane (Philadelphia, 1966). Edition in: Aktensammlung zur Geschichte der Basler Reformation, vol. 6 (Basel, 1950), pp. 403-410; "Das Basler Bekenntnis von 1534," in: Reformierte Bekenntnisschriften, vol. 1/1: 1523-1534, ed. E. Busch, H. Faulenbach (Neukirchen-Vluyn, 2002), pp. 576-583. For later Latin versions of 1561 and 1581 cf.: Corpus et Syntagma Confessionarum Fidei quae in diversis Regnis et nationibus, Ecclesiarum nomine fuerunt authentice editae... (Genevae, 1612; copy BN, XVII.3.8259), pp. 93-97; H.A. Niemeyer, Collectio confessionum in ecclesiis reformatis publicatorum (Lipsiae, 1840). The Confession pays much attention to the Supper. Contrary to the phrases used to describe the Supper, in terms of its content the article is rather Zwinglian in character. In the 1548 edition brief explanations were added to the margins of the particular articles of the Basel confession. Comments on the article about the Supper bear resemblance to Zwingli's theses and refer to the sixth chapter of the Gospel according to St. John. This fragment of the Bible provided Zwingli with one of the key arguments helpful in fighting the views held by the Lutherans; for more on the subject cf. Burnett, Teaching the Reformation, fn. on p. 311; Handbuch der Dogmen- und Theologiegeschichte, vol. 2: Die Lehrentwicklung im Rahmen der Konfessionalität, ed. C. Andresen (Göttingen, 1980), pp. 54-55; W.P. Stephens, "Zwingli on John 6:63: 'Spiritus est qui vivificat, caro nihil prodest'," in: Biblical Interpretation in the Era of the Reformation: Essays presented to David C. Steinmetz in Honor of his Sixtieth Birthday, ed. R.A. Müller, J.L. Thompson (Cambridge, 1996), pp. 156-188. The article of the Confession about the Supper, after another editing in the latter half of the sixteenth century, was given a more Calvinist hue. 
century it came under some criticism, since the way in which it dealt with some issues was no longer in keeping with the development of theological thought and didn't reflect the outcome of a great number of debates that took place in the Reformation camp. All the attempts at editing it (for example, a change in the division of the commandments of the Decalogue, the introduction of the prohibition of the creation of images or the abandonment of the literal interpretation of Christ's descent into Hell) were met with disapproval by the clergy, for years accustomed to Oekolampad's text, and turned out to be effective as late as the beginning of the seventeenth century. ${ }^{44}$

Returning to Wiekszy kaechizm from the 1563 hymnal, it can be stated that the editors of the Polish text made use of Myconius' extended Latin version. It is also worth noting that they preserved the arrangement of particular chapters: reflection on the Creed precedes questions regarding the Decalogue, which was characteristic of the mature Calvinist tradition and the catechetical literature before Luther. It should be noted in passing that Szymon Budny, whom some scholars consider to have been the editor or even the author of Greater catechism, by opening his work with the Decalogue, followed the model proposed by Luther.

What was the translation technique used by the editors of the Polish text? Most of the Institutio Christiana was translated almost literally. Here is the example of the exposition of the fourth article of the Creed.

\section{Institution Christiana}

[Christus] passum autem non sua culpa, (ut qui peccatum non fecit, nec inventus est dolus in ore illius $\{1$ Petr 2 , 22\}) sed nostra, et totius mundi. (fol. A5-A5ver.)

\section{Większy katechizm}

[Chrystus] cierpiał nie dla występkow swych (zwłaszcza gdysz grzechu niegdy nie uczynił ani thesz był falsz w ustach iego nalezion), ale dla złości naszych y wszego świata cierpiał. ${ }^{45}$ (fol. B5)

In the process of translation the Latin text became more developed and various details (or additional terms) were introduced to it without, however, distorting the meaning of the original work. The fragment

${ }^{44}$ Cf. Burnett, “Basel's Long Reformation,” p. 155.

45 Christ suffered not because of his misdeeds (especially that he never committed any sin and no falsehood proceeded out of his mouth) but because of our wickedness and because of the wickedness of the whole world. 
about the effects of the sacrament of baptism is one of those in which such additions were included.

- Facitne lotio Christianum?

- Veluti ianua est ad Christianismum. (fol. $\mathrm{A}_{2}$ ver.)
- A czynisz ono omycie krześcianina? ${ }^{46}$

- Zaiste. Bowiem ono nie inaczey iedno iakoby fortka nieiaka iest, kthorą ku krześciaństwu przychodzim. ${ }^{47}$ (fol. A8)

In some cases the editors of Katechizm większy supplemented Institutio Christiana with more or less extensive, but always significant, insertions. This is exemplified by the fragment devoted to the properties of baptismal water. In the Nieświez version it is stressed that the sacrament has the right effect only on the chosen.

- Tantum valet aqua?

- Non aqua simpliciter, sed aqua baptismi.

- Quid ita?

- Habet Verbum, et Spiritum s. agentem, Verbo mediante, per aquam. (fol. A2ver.)
- A iestże woda tak wielkiey mocy? ${ }^{48}$

- Nie woda prosta: Ale woda ku krzczeniu oddana, $y$ to $w$ tych tylko masz wiedzieć, kthorzy sq z liczby wybranych y przeyrzanych, bo innym nic nie iest pożyteczna. ${ }^{49}$

- A iako to? ?0 $^{50}$

- Ze ma przy sobie słowo Boże

y Ducha świętego, ktory ono wszytko przez śrzodek słowa y wody sprawuie, a then ku ztym nie należy. ${ }^{51}$ (fol. A8ver.)

The fragment about the chosen was included in the exposition of the last article of the Creed regarding the afterlife (fol. B8ver.). Whenever the issue of God's Word is dealt with, the editors of the Nieświez edition always stress the fact that the name is reserved exclusively for

${ }^{46}$ Do you do the washing of a Christian?

47 Verily, there is supposed to be one gate through which we get to Christianity.

${ }^{48}$ Is there a water of such a great power?

49 Not a simple water, but the one destined to baptise. [The water used] to baptise only those who, as you need to know, are among the chosen and selected. It is of no benefit for others.

50 And how is that?

51 That God's Word is with him and the Holy Spirit that acts through word and water and he isn't among evil people. (All the additions and discrepancies between the two catechisms are marked in italics.) 
the Word that had been "truly... prophesied" ("prawdziwie... bywa przepowiedano", fol. B7) and that only the "true" Word can be considered the external sign of the Church (fol. C3ver.).

As compered to the original version Katechizm większy was modified in a way which shows the editors' anti-Trinitarian preferences. The most obvious modifications are those concerning the entire omission of Trinitarian terminology, for example:

$<\ldots>$ Sacrosanctam Trinitatem in divi- $\quad<\ldots>$ w Boga Oyca wszechmocnego, nis: Patrem, et Filium, et Spiritum S.: y w Jezu Krysta syna iego, także tesz Deum unum, personas tres. (fol. A4ver.) w Ducha świętego. ${ }^{52}$ (fol. B3)

The use of the term "Deus" in Institutio Christiana ("unus sit tantus Deus ab aeterno", fol. A4ver.) is almost always accompanied by the respective use of the term "God the Father" in the Polish text ("only God the Father exists from eternity" - "tylko Bog Ociec ieden iest od wiekow", fol. B3ver.; also fol. Cver.). In order to be more precise in expressing their views, the editors of the Nieśwież version added a brief declaration to the exposition of the first article of the Creed: "isz Boga inszego ani mam ani znam, ani tesz chwalę albo wzywam okromia tego iedynego samego ktory iest Oycem Pana naszego Jezusa Krystusa" "I neither have nor know any other God and I neither praise nor call upon any other God except for the one who is Father of our Lord Jesus Christ", fol. B4). Ipso facto Christ isn't treated in Katechizm większy as the Second Person in the Holy Trinity but as Messiah and True Son who is also an intermediary on the road to God the Father:

$<\ldots>$ secundam esse personam in Divinis, unum cum Patre Deum, atque ideo Dominum nostrum. (fol. A5) $<\ldots>$ wyznawam być Panem naszym, żywothem, drogą, prawday pośrzednikiem do Boga Oyca. ${ }^{53}$ (fol. B4B4ver.)

The issue of intermediation recurs many times in the Nieśwież version (i.a., fol. B6), Christ's true humanity is also stressed a couple of times (fol. B4ver.). The Holy Spirit is referred to in Większy katechizm only as "our comforter and our guide to the truth" ("naszym pocieszycielem, wodzem ku wszelakiey prawdzie”, fol. B6ver.).

52 In God the Father Almighty and in Jesus Christ, his Son and also in the Holy Spirit.

53 I believe Him to be our Lord, our Life, our Path, our Truth and our Intermediary to God the Father. 
Particular motives were thoroughly reworked in Większy katechizm. A case in point here is the exposition of the fragment regarding Christ's descent into Hell. I have mentioned above that Oekolam$\mathrm{pad} /$ Myconius' work was more typical of the medieval tradition and raised serious doubts already among their successors. The editors of the Nieśwież catechism offer a different explanation of the issue. Abandoning the literal understanding of the descent, they tend to interpret it in terms of Christ's experience of God's wrath and His acceptance of the humility of the whole world. That none of the faithful can either enter or leave Hell is testified, for example, by an evangelical parable about the rich man and Lazarus. Along Unitarian lines Katechizm większy throws into doubt the very existence of this article in apostolic teachings: "Wszakże y tho wiedzieć masz, isz ten Artykuł nie nayduie się u wiela starych Pisarzow, stąd się znaczy isz musiał być nie od Apostołow uczyniony" ("You should know that this Article is absent from many old writers, which means that it doesn't come from Apostles", fol. B5-B5ver.). ${ }^{54}$

This article of the Creed is directly followed by the only anti-Jewish polemical remark that appear in Institutio Christiana: the Jews are wrong to think that Christ remained on earth after his death. The motif is preserved in Katechizm większy and the only fragment that is omitted is the one about Messiah:

Dominus non mansisse in terris (quod Iudaicus error de Messia conceperat) $<\ldots>$. (fol. A5ver.)
Wyznawam że Krystus w grobie (iako się na tym Zydowie myla) nie został. ${ }^{55}$ (fol. B5ver.-B6)

Among the significant changes introduced into the original text in the course of its translation into Polish, one needs to mention a different division of the Ten Commandments (4+6 instead of 3+7, as in Oekolampad/Myconius version), the one which was more in line

${ }^{54}$ It should be noted that the identification of the descent into Hell with Christ's torment was also a trait of the teachings of John Calvin (cf. idem, Institutio Christianae religionis, II, XVI, $\$ 10$ ), who raised the issue for the first time in his polemic with Anabaptists regarding the faithful's afterlife (written in 1534, the work Vivere apud Christum non dormire animis sanctos qui in fide Christi decedunt, quae vulgo Psychopannychia dicitur appeared in print only in 1542. For more cf. A. Tokarczyk, Jan Kalwin (Warszawa, 1989), p. 31. Calvin refers here to Erasmus of Rotterdam's exposition of this fragment of the Creed.

55 I believe that Christ (and this is where the Jews are wrong) didn't remain in His grave. 
with the way in which the biblical text was divided by Reformed evangelicals. In translating Institutio Christiana the Nieśwież editors also removed the quotation from St. Augustin regarding the external signs of the true Church, although the translation of the fragment is almost literal (fol. B7ver.). Two new questions and answers were added elsewhere in the text. One of them, devoid of any confessional hue, is concerned with explaining the question of "coveting the goods of one's neighbour” („porządanie rzeczy bliźniego”, fol. C4). The other one appears to contain the hidden polemic with the believers of the Holy Trinity and, as such, is much more interesting:

- A ktorysz ten iest, co Bogi insze miewa?

- Ktory własną cześć Boga żywiącego chocia dobrze wnamnieyszey cząstce ku czemu inszemu obraca albo tesz gdy od kogo innego ratunku y pomocy szuka, albo się spodziewa, a nie od samego iednego Boga żywiącego. ${ }^{56}$

The passage quoted above appears in the context of the exposition of the second Commandment but doesn't refer to idolaters those are dealt with in the next question: „Kogosz ty sobie masz za bałwochwalcę?" ("Whom do you consider an idolater?”, fol. C2ver.).

It is interesting to note that although the editors of the Nieświez edition gave the catechism an anti-Trinitarian hue, they didn't remove the fragment taking a negative view of rebaptism. Let's recall that the problem is touched on in Oekolampad's Frag und Antwort in connection with his polemic with Anabaptism. Katechizm większy is more developed here (and at many other points throughout the text) than the Latin version (the most significant lexical discrepancies are marked in italics).

- Velles et tu rebaptizari, si quis fanaticus exposceret?

- Absit, per Dominum semel baptizatus sum, et inscriptus in albo Christianorum non opus est igitur anabaptismo. (fol. B)
- A gdyby cztowiek niektory niezboziny $y$ obtudny na to cie namawiat, y od ciebie tego żądat, aby się znowu powtore okrzcił, usłuchałżebiś go w tym? ${ }^{57}$ - Boże tego nie day, abych iego w tey mierze słuchać miał, w imię bowiem Pańskie ras okrzczon y $\mathrm{w}$ poczet innych Krześcianow wpisan iestem, nie

56 And who is the one who has other Gods? - He who turns the smallest particle of his worship of the feeding God into something else and who seeks or expects help and salvation from someone else than the feeding God.

57 And if an impious and duplicitous man tried to persuade you to re-baptise yourself and if he called for you to do it, would you agree to this? 
iest mi tedy tego żadna potrzeba abych zaś powtore krzcić się wodq miat. ${ }^{58}$ (fol. C4ver.-C5)

To be sure, minor clarifications introduced into the Nieśwież version are evidence that it is rebaptism only by water that is criticised here. This conclusion is followed by a discussion of Christ's words addressed to children: "Takowych iest Krolestwo niebieskie" ("for it is to such as these that the kingdom of heaven belongs", Mt 19:14). What our Saviour says here: "nie zgoła o krcie [!] rozumiem, ale o krzcie ktory przy sobie ma wyznanie wiary albo radniey samę żywą wiarę wlaną od ducha świętego" ("doesn't refer to baptism alone, as I understand it, but to baptism that is accompanied by the profession of faith or even by the living faith itself poured by the Holy Spirit", fol. C5-C5ver.). The editors of the catechism aren't plainly opposed to the baptism of children, but this is what they mean when they claim that the faith of those who are about to be baptised is the condition on which their baptism depends. And from this it follows that it is simply pointless to baptise children. ${ }^{59}$

58 God forbid I should agree. Having been baptised in the name of our Lord, I joined the ranks of Christians and there is no need for me to be baptised by water again.

59 The Nieśwież hymnal was created at the time when Lithuania saw the beginning of the discussion of the baptism of children. It was formally instigated by a letter which Piotr of Goniądz wrote about the subject to the Nieśwież minister Wawrzyniec Krzyszkowski. In this connection, a synod was called in Wilno at the end of 1562 or at the beginning of 1563. In its course "it was proposed that children shouldn't be baptised until they reached seven years of age. This caused indignation of all of their adherents. That is why they gathered again and agreed to baptise children the way they had always done” („na którym [...] postanowiono, między innymi, aby dzieci się nie chrzciło do lat siedmiu; na co ogół ich zwolenników bardzo się oburzył, stąd to na nowo musieli się zgromadzić i dozwolić, aby chrzcić je jak dawniej"; quoted after: L. Szczucki, Marcin Czechowic (1532-1613). Studium z dziejów antytrynitaryzmu polskiego XVI wieku [Warszawa, 1964], p. 46). Testimony to the discussion that had already continued for some time was an article which Szymon Zaciusz wrote in defense of the baptism at childhood age and which he included in Wyznanie wiary zboru wileńskiego (1559). Interestingly, before 1563 Szymon Budny as one of the possible editors of Większy katechizm occupied a traditional position on this issue, while in his Katihisis... he stressed that "proto i teper deti mogut sâ krestiti, hotâ žby very nie meli” (quoted after reprint in: Katēhizis: Pomnik belaruckaj Réfarmacyi XVI st., ed. N. Kabelka [Minsk, 2005], p. 282). A dozen or so years after the publication of the Nieświez hymnal Szymon Budny returned to this 
What has hitherto been said challenges the hypothesis that Katechizm wieksszy is a translation of the 1562 Cyrillic Katihisis. Almost all passages that Alodia Kawecka-Gryczowa consider to be borrowings from Szymon Budny actually come from Oekolampad/Myconius. I will give here just one example. According to this scholar it was Budny who included in Większy katechizm the discussion regarding the choice of company, temperance in drinking and eating and so on. ${ }^{60}$ However, this fragment is an almost literal translation of Institutio Christiana.

- Ocium ut fugitas?

- Parentum iussis obedio: et diligentiam mihijpsi impero ad aliquid discendum, vel agendum, ut eis placeam: in publicum emissus, festino.

- Quales adiungis tibi socios?

- Fugio qui turpia loquuntur, qui maledicunt, qui iurant, qui ludunt, qui mentiuntur, quique a templi abhorrent ingressu: contra vero semper sunt in ocio, et versantur in plateis. Illis autem me adplico, quibus literarum placent studia, qui virtutem colunt, et timore Dei non vacant.
- Co zaś czynisz abyś się prożnowania mogł uwiarować? ${ }^{61}$

- Posłuszen iestem rodzicom moiem, y prawie sam sobie pilność w uczeniu albo w inszich rzeczach czynieniu roskazuię, abym się onym spodobał, a gdy mi tesz co slecą albo mię gdzie poslą, chutko wszytko sprawuię. ${ }^{62}$

- Towarzystwa iakiego sobie nabywasz? ${ }^{\text {?3 }}$

- Ktorzy plugawo mowni są, bluznierze złorzeczący, kosterowie, krzywoprzysięscy, pijanice, gracze, fałszerze, ktorzy tesz nie radzi słowa Bożego słuchaią, a ktemu się w prożnowaniu kochaią, tych się iak iadu wiaruię: ktorzy się lepak w dobrym ćwiczeniu, w cnotach y boiaźni Bożey roskoszuią, o tych się towarzystwo staram y s nimi rad bywam. ${ }^{64}$

issue in his treatise against the baptism of children entitled $O$ dzieciokrzczeństwie krótkie wypisanie.

${ }^{60}$ Cf. Kawecka-Gryczowa, "Kancjonały," p. 130.

61 What do you do to avoid idleness?

${ }^{62}$ I obey my parents and in order to please them I apply myself almost through my own orders to my studies and to all the other tasks I perform. When they want me to do something or want to send me somewhere, I do it all.

63 A company you provide yourself with?

64 Those who use a filthy language, blasphemers, perjurers, drunkards, gamblers, forgers, those who aren't willing to listen to God's word and who love loafing about - these I shun like a poison. And those who love exercising their virtues and who revel in their fear of God, I seek their company and try to stay around them. 
- Quo modo teipsum curas?

- Co tesz za staranie sam o sobie masz? ${ }^{65}$

- Edo et bibo, quantum satis est: - Jem y piję ile iest potrzeba, a o hoyne non quaero cibos lautiores: excitatus de somno, protinus surgo: et loquor, rogatus.

y kosztowne się pokarmy nie staram. Gdy czas spać spię, gdy tesz zaś iest czas powstania, chnet zaraz wstanę, y na to o co mię kiedy pytaią odpowiedam. ${ }^{66}$

- Prohibuit ne tibi Deus cibum aliquem, aut potum?

- Haud quaquam: sed crapulam pro- A zakazałzeć tesz Bog iedła albo napoiu ktorego? ${ }^{67}$

- Zaiste nie, lecz obżerstwa y opilstwa hibuit, ac ebrietatem. Donis eius uti valeo cum gratiarum actione, quamobrem ante et post cibum orare soleo. (fol. B4ver.-B5)

tego mie iest srodze zakazał, darow iego ia używać mogę z dziękow czynieniem, dla czego tesz y przed iedłem wzywać y modlić się iemu, naiadwszy się lepak dziękować iestem się zwyczaieł. ${ }^{68}$ (fol. D3ver.-D4ver.)

It must be stated that it is a little out of place for the fragment presented above to go after the exposition of prayer and the suggestions about how to listen to God's Word and before the exposition of Lord's Supper. It would fit in better with the remarks regarding the Decalogue.

Among the possible borrowings from Budny's texts are the fragments that were treated differently in the Latin version of Oekolampad's catechism. These motifs seem to include the reflections on Christ's descent into Hell. Budny pays a lot of attention to this issue in his Katihisis. According to scholars, it is the issue that is given the most detailed treatment in the whole catechism. ${ }^{69}$ Budny's main intention was to fight members of the Orthodox Church. Lifted verbatim from Katihisis appears to be the sentence: "Pan Krystus sstąpił (!) do Piekłow, to iest, uczuł gniew Boży dla grzechow świata wszego, ktore

${ }^{65}$ How do you care about yourself?

${ }^{66}$ I eat and drink as much as I need and I don't care about lavish and costly food. I sleep when it is time to sleep and I get up when it is time to get up. I also answer questions I am asked.

67 And had God forbidden us to eat or drink something?

${ }^{68} \mathrm{He}$ doesn't. But he strictly forbade gluttony and drunkenness. I can use his gifts expressing my gratitude. That is why I pray before eating and I am in the habit of thanking Him afterwards (fol. D3ver.-D4ver).

${ }^{69}$ Cf. Kamieniecki, Szymon Budny, p. 31. 
był nasię wziął" ("Christ descended into Hell, that is, felt God's wrath for the world's sins which He took upon himself”, fol. B5), the claim that the descent is an invention, in the strict meaning of the term, of monks ("iako Mniszy baią" - as monks fable) and the remark: "isz ten Artykuł nie nayduie się u wiela starych Pisarzow, stąd się znaczy isz musiałbyć nie od Apostołow uczyniony" ("that this article is absent from many ancient writers, which means that it doesn't come from Apostles", fol. B5ver.). ${ }^{70}$

It is impossible to establish how the Basel edition found its way into the Great Duchy of Lithuania. Basel is known to have been one of the destinations of both Polish and Lithuanian youth going to European academic centres to study. Until mid-sixteenth century most of those who went to Basel were from Little Poland (Małopolska), but from 1560 on the city began to be visited by an increasing number of students and wanderers from Lithuania, usually of the Calvinist affiliation ${ }^{71}$ (many of them became later adherents of anti-Trinitarianism). ${ }^{72}$ In 1547 Jan Mączyński (1520 - before 1580), a lexicographer, the Reformation activist and a secretary to Radziwiłł Czarny ${ }^{73}$ - a powerful protector of the evangelicals, spent a few months in Basel. Institutio Christiana may also have been brought to Lithuania by a distinguished activist of Polish anti-Trinitarianism Marcin Czechowic (1532-1613) who in the latter half of 1561 and at the beginning of 1562 was in Switzerland where he was sent by Radziwiłł on a mission to reconcile Calvin and Bullinger with George Blandrat (about 1515/1516-1588). On his way back he visited Basel where he became acquainted with Piotr Pern (1520-1582), a wellknown Basel printer closely connected with the heterodox circles. ${ }^{74}$ It is known that upon his return to Wilno Czechowic was involved in composing the Nieśwież hymnal, which contains his songs. The songs

${ }^{70}$ Cf. Katēhizis, pp. 176, 178.

${ }^{71}$ Cf. "Polacy w Bazylei w XVI wieku. Z metryk Uniwersytetu Bazylejskiego," ed. J. Kallenbach, in: Archiwum do dziejów literatury $i$ oświaty $w$ Polsce, vol. 6 (Kraków, 1890), pp. 1-9; M. Włodarski, Polsko-bazylejskie więzi kulturalne i literackie $w$ XVI wieku (Kraków, 1987), p. 54.

72 Cf. S. Kot, "Polen in Basel zur Zeit des Königs Sigismund August (1548-1572) und die Anfänge kritischen Denkens in Polen," Basler Zeitschrift für Geschichte und Altertumskunde 41 (1942), p. 147.

73 Cf. Włodarski, Polsko-bazylejskie więzi, pp. 36-37; M. Chachaj, Zagraniczna edukacja Radziwittów od początku XVI do potowy XVII wieku (Lublin, 1995), p. 17.

74 Cf. S. Kot, "Czechowic, Marcin," in: Polski stownik biograficzny, vol. 4 (Kraków, 1937), pp. 307-308; Szczucki, Marcin Czechowic, p. 37. 
were included both in the song book and in its supplement dated to 1564 . One may argue that the inclusion of Większy katechizm in the Nieśwież hymnal has to do with a catechism which Czechowic prepared, published and taught in Wilno ("którego w Wilnie uczył i wydał"). We know about its existence from a laconic reference by Radziwiłł's doctor, Kasper Wilkowski who later left the Arian community and converted to Catholicism. ${ }^{75}$

One can only guess why the editors of the Nieśwież hymnal made use of Oekolampad/Myconius catechism and what its special qualities were that determined their choice. It may have been affected by the ambiguity and obscurity of some of the statements of the Latin version, which Myconius created in an effort to find a compromise between the opposing theological views of Wittenberg and Zurich.

Oekolampad may also have aroused some interest among the Lithuanian advocates of anti-Trinitarianism because Basel reformer was in constant touch with the Anabaptists and was also charged with the denying of the existence of the Holy Trinity. The charges were raised by Martin Luther during the religious debates in Marburg in 1529. ${ }^{76}$ Being part of the Nieśwież hymnal Większy katechizm remains an interesting episode in the history of the Reformation writings of the Great Duchy of Lithuania.

\begin{abstract}
This study is an analysis of the text and sources of the Calvinistic catechism printed in the Nieśwież hymn book (1563), which was previously regarded as a compilation from Sz. Budny's cyrillic text (1562). The given catechism is a revised translation of the most influential of the Basel Manuscripts, prepared by I. Oekolampad ca. 1525-1529 and edited by his successor O. Myconius as Institutio Christiana in 1544. The Polish version of the Basel Manuscripts reflects the progress of this dogmatic profile of Calvinism in the Polish-Lithuanian Commonwealth and the influences of anti-Trinitarianism in Calvinistic instructive and catechetical literature.
\end{abstract}

${ }^{75}$ Cf. Przyczyny nawrócenia do wiary Powszechney od Sekt Nowokrzczeńcow Samosateńskich (Wilno, 1583), p. 136.

${ }^{76}$ Cf. Wilbur, A History of Unitarianism, p. 16. 
Margarita Korzo studied history in Moscow and Budapest. Having received the PhD (1999), she is employed as senior research fellow at the Institute of Philosophy, Russian Academy of Sciences in Moscow. She is the author of three books and over 120 articles in Russian, Polish, Ukrainian, German and English. Her scholarly interest focuses on the religious literature and the interaction of various confessional traditions in the Polish-Lithuanian Commonwealth in the sixteenth-eighteenth centuries, as well as the influences of Polish literature on the Russian one in this period.

E-mail: ma.korzor@gmail.com

Trans. by Artur Mękarski

First published as: "Przyczynek do roli druków bazylejskich w XVI-wiecznym piśmiennictwie ewangelickim Wielkiego Księstwa Litewskiego," Odrodzenie i Reformacja $w$ Polsce 55 (2011), pp. 7-26

The publication of this English translation has received additional funding from the Ministry of Science and Higher Education of the Republic of Poland 